


\title{
Gold Content of Water, Plants, and Animals
}

\author{
By Robert S. Jones
}

GEOLOGICAL SURVEY CIRCULAR 625 
United States Department of the Interior ROGERS C. B. MORTON, Secretary

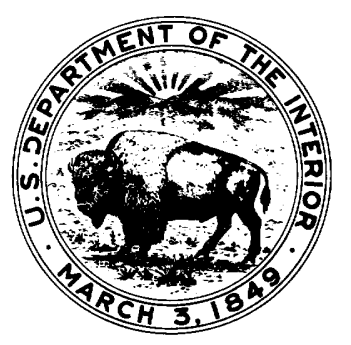

Geological Survey

V. E. McKelvey, Director

First printing 1970

Second printing 1973

Free on application to the U.S. Geological Survey, Washington, D.C. 20244 


\section{CONTENTS}

Abstract.

Introduction.

Gold content of water.

Sea water

Fresh surface water

Ground water.

Summary

Gold content of plants.

Algae

Fungi. _

Lichens_.

Mosses

Herbs

Shrubs_ _

Trees.-1

Summary

Gold content of animals

Summary.

References cited.

TABLES

Table 1. Gold content of seas

2. Gold content of plants

3. Gold content of marine animals. 



\title{
GOLD CONTENT OF WATER, PLANTS, AND ANIMALS
}

\author{
By Robert S. Jones
}

\section{ABSTRACT}

Sea water contains from 0.001 to $44 \mathrm{ppb}$ (parts per billion) gold. The amounts of gold in fresh surface waters and ground waters are also within this range. The average amount of gold in sea water as calculated from neutron activation analyses is $0.05 \mathrm{ppb}$.

The maximum amount of gold detected in plant ash by neutron activation methods is $36 \mathrm{ppm}$ (parts per million) and the average is about $7 \mathrm{ppm}$. This average, if correct, greatly exceeds the average concentration of gold in the earth's crust.

The gold content of dry matter in animals as determined by neutron activation methods ranges from 0.0012 to $430 \mathrm{ppb}$. On the basis of scanty analyses, terrestrial plants and animals appear to contain more gold than marine plants and animals.

\section{INTRODUCTION}

This report on the gold content of water, plants, and animals is one of four that summarizes available data on the occurrence of gold. The other reports are on gold in the earth's crust, in rocks, and in minerals (Jones, 1968, 1969; Jones and Fleischer, 1969). They have been prepared as background material for the Heavy Metals program of the U.S. Geological Survey, an intensified program of research on new sources of heavy metals, including gold.

Data on the gold content of ocean waters and of fresh waters, as well as on the gold content of various plants and animals, are summarized and collated. Conclusions drawn from the data must be tentative because of lack of standardization among analytical techniques.

\section{GOLD CONTENT OF WATER}

The concentration of gold in the hydrosphere is not likely to exceed $0.01 \mathrm{ppb}$ (part per billion), according to Zvyagintzev (1941), but this amount seems to be nearer an average value than an upper limit. It is appreciably lower than the range from
1 to $6 \mathrm{ppb}$ given as the average gold content of the earth's crust (Jones, 1968).

\section{SEA WATER}

Sonstadt (1872) was the first to make analyses of sea water for gold and gave three methods for doing so, but he obtained evidence of gold in sea water by only one of them. Since then man has dreamed of economically extracting gold from sea water. Probably the foremost of the analysts was Haber (1927, 1928) who devoted many months of research to this problem, only to foresake it when he realized from the analyses of a large number of samples of sea water that its gold content was very much less than had been previously reported. The amount of gold per cubic meter of sea water is minute and, according to Haber (1928), as based on the analyses of 1,635 samples taken at 186 stations across the South Atlantic Ocean (table 1), is $0.004 \mathrm{ppb}$. The amount of gold in sea water is estimated to be 27.4 million tons (Friedensburg, 1953).

The analyses of gold in sea water are given in table 1. Analyses made prior to 1927 are not included, but those who wish to refer to these can consult the works of Sondstadt (1872), Pack (1898), Liversidge (1897), Don (1898), Wagoner (1901), DeWilde (1905), and Koch (1918).

The seas and oceans contain varying concentrations of gold. For instance, the South Atlantic Ocean has been considered by Haber to be gold poor when compared to the amount in the other seas and oceans. Haber found at least ten times more gold for a given volume of water in the North Atlantic Ocean than he did in the South Atlantic Ocean. Other workers have also found a higher average amount (table 1). Not only do the oceans 


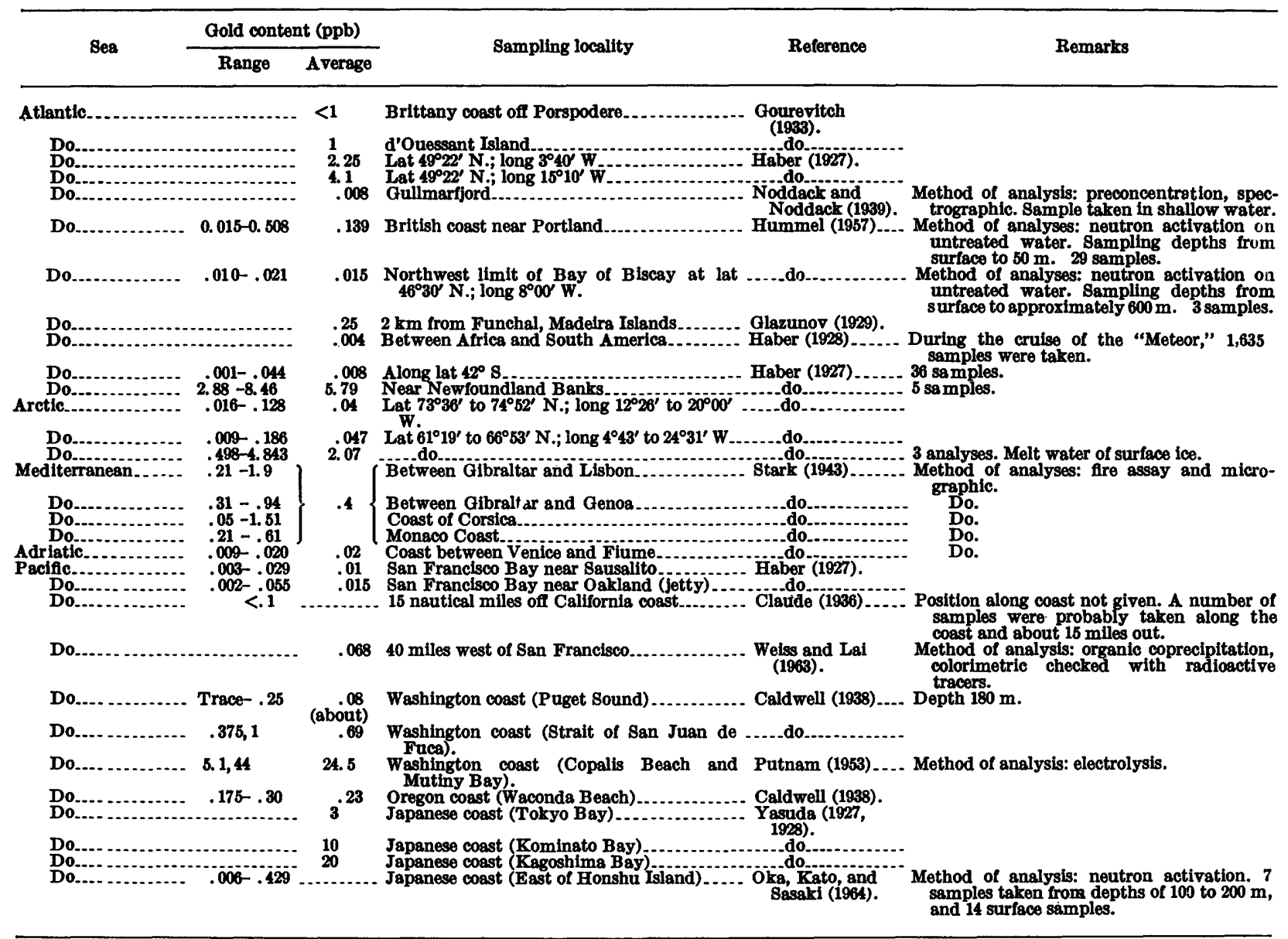

and seas vary in the amount of gold that they contain, but so do samples taken simultaneously "side by side" (Hummel, 1957).

Haber (1927), probably hoping to find larger amounts of gold in sea water near goldfields, analyzed more than 100 samples of sea water from San Francisco Bay, just off Sausalito and Oakland. The waters near Oakland contained as much as $0.055 \mathrm{ppb}$ and had a median value of $0.012 \mathrm{ppb}$ gold. The time of day that the samples were taken and the ebb and flow of the tide seemed to be insignificant factors in the amount of gold found in the analyzed sea water. Farther from shore, 40 miles west of San Francisco, the ocean water contained $0.068 \mathrm{ppb}$ gold (Weiss and Lai, 1963).

Hummel (1957) found 0.015 to $0.5 \mathrm{ppb}$ gold in sea water; Caldwell (1938), Stark (1943), and Putnam (1953) obtained values of from 0.02 to 44 ppb (table 1). Caldwell (1938) concluded that there is a maximum of about 0.1 to $0.2 \mathrm{ppb}$ gold in the sea water off the Oregon coast or in Puget. Sound (Washington). However, these figures might be low considering the values given by
Putnam. Stark noted that samples of water from the Adriatic Sea contained an average of $0.02 \mathrm{ppb}$ gold and from the Mediterranean Sea, 0.4 ppb. The maximum amount of gold in sea water obtained off the Iberian coast was almost $2 \mathrm{ppb}$.

Sea water off the coast of eastern Japan has been taken from various depths and analyzed for gold by the neutron flux method (Oka, Kato, and Sasaki, 1964). The amount of gold found ranged from 0.006 to $0.429 \mathrm{ppb}$. The content varied in different places, but the amount of gold in deeper waters was somewhat less than that found in surface waters. Where cold and relatively warm waters mingled, such as the cold Kuril current (Oya Shio) with the warmer Black current (Kuro Shio) (Zenkevitch, 1963), the gold content was relatively high. Analyses from other places near the Japanese coast indicated the gold content of sea water ranged from 3 to $20 \mathrm{ppb}$ (Gmelin, 1954, p. 125-130).

In one locality, during a spring bloom of phytoplankton, a decrease of about 15 percent in 
dissolved silicate contents occurred, and the gold contents decreased 60 percent (Hummel, 1957).

Peshchevitskii, Anoshin, and Erenburg (1965) believe that gold in sea water is present mostly in the form of the complex anion $\left(\mathrm{AuCl}_{2}^{-}\right)$, although this was contrary to Haber's (1928) conclusion that gold was associated with particulate matter. Schutz and Turekian (1965) question Haber's conclusion stating: "The precision of his (Haber's) determination of four centrifuged samples was no better than on the original water, so the association of gold with particulate matter does not seem to be the primary contribution to analytical variance in his method."

Hummel (1957), though, believes that gold concentration tends to decrease away from shore and agrees with Haber that the gold is associated with particulate matter because of the inconsistent variability of gold content with depth from the surface of the water downward and also the decrease in the gold contents as samples are obtained progressively farther from shore.

\section{FRESH SURFACE WATER}

River waters have been considered as being too low in gold content to make them worthwhile as a tool for geochemical prospecting for gold in gold-bearing regions (Konovalov, 1941), although Kropachev (1935) considers values of $0.06 \mathrm{ppb}$ and more gold in water as being useful for prospecting purposes. In the rivers of the Irkutsk region and Transbaikal, the gold values are mostly from 0.01 to $0.09 \mathrm{ppb}$, in the Krestovka $0.016 \mathrm{ppb}$, the Zarca $0.33 \mathrm{ppb}$, the Unda $1.7 \mathrm{ppb}$, the Gazimur 4.7 ppb, and water from Lake Baikal at the mouth of the Krestovka River $0.12 \mathrm{ppb}$ (Kropachev, 1935). Samples of water from the Sutar River contained 0.005 to $0.01 \mathrm{ppb}$ of gold and averaged $0.03 \mathrm{ppb}$ (Konovalov, 1941). Rhine River waters near Karlsruhe averaged 0.0039 ppb gold, near Leverkusen $0.0027 \mathrm{ppb}$ of gold, and near Schöpfstallen, $0.003 \mathrm{ppb}$ gold (Haber and Jaenicke, 1925). Fischer (1966) found $2 \mathrm{ppb}$ gold in unfiltered Saale River water and $0.1 \mathrm{ppm}$ (part per million) gold in the suspended matter.

\section{GROUND WATER}

Thermal waters rising from great depths are known to contain gold. The gold content in the deep waters of the Comstock Lode, whose temperatures vary from $116^{\circ}$ to $170^{\circ} \mathrm{F}$, is $0.298 \mathrm{ppb}$ (Lincoln, 1911). Vadose water at the Comstock Lode contains both gold and silver in solution.
Studies of gold in hot springs of Beppu (Jipan) were made by Koga $(1960,1961)$. The average gold content of 27 springs was $0.53 \mathrm{ppb}$, ranging from 0.5 to $2.2 \mathrm{ppb}$ gold. At the Motoyu spring at Nasu (Japan) is deposited a yellow precipitate which contained 1 to $10 \mathrm{ppm}$ gold (Ikeda, 1955b). The gold content of some acid spring waters is less than $0.01 \mathrm{ppb}$ (Ikeda, 1955a).

At Lake Taupo, New Zealand, sinter deposited by existing hot springs yielded $0.94 \mathrm{ppm}$ gold. Maclaren (1906) noted that some siliceous sinter from Whakarewarewa south of Rotorua, New Zealand, contained about $1 \mathrm{ppm}$ gold, whereas a nearby sulfurous sinter contained about $2 \mathrm{ppm}$. Grange (1937) reported 2 ppm gold and 120 ppm silver in the sinter from Whakarewarewa. The metal content of precipitates in some hot springs and boreholes in New Zealand ranged from $<1$ to $85 \mathrm{ppm}$ gold and from $<5$ to $500 \mathrm{ppm}$ silver (Weissberg, 1969). One of these springs, the Champagne Pool at Waiotapu, whose source is possibly as deep as 1.5 to 3 kilometers, has an areal extent of 7,000 square meters, a surface temperature of $70^{\circ}$ to $75^{\circ} \mathrm{C}$, and a $\mathrm{pH}$ ranging from 4.9 to 6.5. Samples of its sinter contained $80 \mathrm{ppm}$ gold and $175 \mathrm{ppm}$ silver. The gold content of the hot waters from another spring was $\leq 0.04$ $\mathrm{ppb}$ and from one borehole was $0.04 \mathrm{ppb}$. Analyses of sinter from Steamboat Springs, Nev., have been reported as $1 \mathrm{ppm}$ gold (Becker, 1888) and as $10 \mathrm{ppm}$ gold and $400 \mathrm{ppm}$ silver (White, 1967). At Boulder, Mont., a vein filling deposited by an existing hot spring contained $0.768 \mathrm{ppm}$ gold; at Anaconda, Mont., the gold content of a ferruginous tufa deposited by an existing hot spring varied from 0.83 to $2.49 \mathrm{ppm}$; and at Ojo Caliente, N. Mex., a calcareous tufa deposited by an existing hot spring yielded $0.042 \mathrm{ppm}$ gold (Lincoln, 1911). A water sample from the Great Salt Lake contained an equivalent of $0.032 \mathrm{ppm}$ gold (Lincoln, 1911). Because some of the foregoing analyses were made before about 1928 , prior to the development of modern analytical techniques for gold, it is possible that some of them may be inaccurate (Coates, 1939).

Waters flowing through mines in the Aldan Shield of the southern Yakut, U.S.S.R., contained an average of $0.7 \mathrm{ppb}$ gold, and stagnant mine water contained $0.9 \mathrm{ppb}$ gold (Razin and Rozhkov, 1963). In other ground waters the minimum amount of gold as determined by Landstrom and Wenner (1965), using neutron-activation method of analysis, was $0.001 \mathrm{ppb}$. 
SUMMARY

The amount of gold found dissolved in sea water ranges from 0.001 to $44 \mathrm{ppb}$. The amount of gold commonly found in ground waters and river waters is also within this range. The amount of gold in sea water, as determined by neutron-activation methods, averaged about $0.05 \mathrm{ppb}$ in contrast to the $0.004 \mathrm{ppb}$ reported in the older work of Haber (1928) and appears to be highest near the continents and lowest in the deep ocean. A few analyses of spring waters show that the gold ranges from 0.01 to $2.2 \mathrm{ppb}$ and averages about $0.5 \mathrm{ppb}$. Other ground waters contained from 0.001 to $0.9 \mathrm{ppb}$ gold. River waters contained from 0.003 to $4.7 \mathrm{ppb}$ gold. Zvyagintzev (1941) has stated that the amount of gold in the hydrosphere is not likely to exceed $0.01 \mathrm{ppb}$. In view of the foregoing values this is low.

\section{GOLd Content of plants}

One of the oldest references to the occurrence of gold in plants was by Malte-Brun (1847) who referred to the work of Sage, Berthollet, Rouelle, Darcet, and Deyeux. Berthollet was reported to have extracted about $44 \mathrm{ppm}$ gold from the ashes of vegetables.

Zvyagintzev (1941) thought that plant-root secretions and humic acids should definitely act as solvents for gold, and that this solubilization is the first process leading to the uptake of gold in plants. After the death of the plants, metals are retained in the humus (Malyuga, 1964; Curtin and others, 1968). Deul (1958) found gold in the ash of the humic acid fractions of peat. He did not detect it in plant ashes, in the whole peat ash, or in any other fraction that he separated from the peat. In seven samples Deul obtained from 1 to $10 \mathrm{ppm}$ gold in the ash of the humic acid extract. Bouska, Havlena, and Sulcek (1963) in their observations on coal concluded that gold is bound predominantly, although not: exclusively, to the organic part of coal.

The gold content of plants is given in table 2 . The amount of gold is reported in the plant ash or in the dry plant. Also given are the ash contents of many of these plants and the amount of gold found in the soil near the plant. The values for gold in soil given by Razin and Rozhkov (1966) are the maximum values found and usually are of the $\mathbf{C}$ horizon of the soil. The nonvascular plants have been divided into algae, fungi, lichens, and mosses and the vascular plants into herbs (grasses and sedges, and forbs), shrubs, and trees. Most analyses given in table 2 are of vascular plants.
Some workers have noted that plants have a higher metal content at certain times of the year. Malyuga (1964) commented that toward autumn the leaves of trees have two to three times as much nickel, cobalt, and copper as they have during the spring. By contrast, Aripova and Talipov (1966) reported that the ash of wormwood (Artemisia) contained from 10 to 20 times more gold, copper, lead, and chromium in May than in October and that these metals are especially accumulated in plants in desert regions.

\section{ALGAE}

The ash of several marine algae have been analyzed for gold (table 2). Stark (1943) found $1.7 \mathrm{ppm}$ gold in the ash of unspecified seaweeds from an unspecified locality. By contrast, Fukai and Meinke (1962) using activation methods of analysis, reported 0.00015 and $0.00093 \mathrm{ppm}$ gold in the ash of two samples of sea lettuce, Ulva sp. In the dry matter of these samples, one from Tokyo Bay, Japan and the other from Sagamu Bay, Japan, the amount of gold in one sample was $0.000035 \mathrm{ppm}$ and, in the other, $0.00021 \mathrm{ppm}$. It is notable that these values are within the range of $0.000006 \mathrm{ppm}$ to $0.000429 \mathrm{ppm}$ gold found in sea water (table 1) east of Honshu Island, Japan by Oka, Kato, and Sasaki (1964) who also used neutron-activation methods of analysis. Because of this, and the fact that the gold in the ash of the two plants is about one order of magnitude less than the amount of gold given for the earth's crust (Jones, 1968), sea lettuce does not appear to be an accumulator of gold.

\section{FUNGI}

Fungi are known to contain from trace amounts to $11.6 \mathrm{ppm}$ gold in their ash. Those containing $1 \mathrm{ppm}$ or more are all Boletus.

\section{HCHENS}

The ashes of three lichens, Cladonia alpestris, Cladonia gracilis, and Peltigera aphthosa averaged $1.0,1.3$, and $1.0 \mathrm{ppm}$ gold, respectively. The amount of gold in the ashes of these plants averages twice the amount of that in the soil.

\section{MOSSES}

Although Shacklette (1965) found no gold in an unspecified number of liverworts and mosses, Razin and Rozhkov (1966) recorded from 0 to $19.2 \mathrm{ppm}$ gold in the ashes of mosses which they analyzed. No gold was detected in Sphagnum fimbriatum and a sample of Aulacomnium palustre. In table 2 the maximum amount of gold reported 


\section{TABLE 2.-Gold content of plants}

[ Some results were reported as 0 ppm gold; however, gold was probably present but not in sufficient amount for detection. In remarks column, number in parentheses is the amount of gold, in parts per million, in the soil near the plant]

\begin{tabular}{lccc}
\hline Organism & $\begin{array}{c}\text { Content in } \\
\text { ash (ppm) }\end{array}$ & Reference \\
\hline
\end{tabular}

\section{NONVASCULAR PLANTS}

Algae

"Besweed"

Uloo sp. (sea lettuce) Do. (sea lettuce) - . .................

Boletus bulbosus

Boletus edulis.

(n)

Boletus luteus. .........................

Boletus rufus.

Do

Boletus scaber

Morchella conica

Polyporus fomentarius

Cladonia alpestris (L.) Raben. (reindeer Lichen).

Cladonia gracilis (L.) Willd. (reindeer lichen).

Peltigera aphthosa (L.) Hoffm. (dog lichen).

Aulacomntum palustre
Schwaegr.
Camptothecium nitens
Schpr.
Drepanocladus sp.-
Polvtrichum hyperboreum.)
(haircap moss).
$\begin{aligned} & \text { Sphagnum fimbriatum } \\ & \text { (sphagnum). }\end{aligned}$

Agrostis alba L. (Redtop bentgrass) - -

Agrostis trinii Turc 3.

Calamagrostis langsdorffi (Link)

Trin. (bluejoint gr' $\mathrm{ss}$ ).

Calamagrostis lapponica (Wahl.)

Hartm.

Carex sp. (sedge).

Carex pediformis C.A.M

Carex vanheurkii Muell.

Hordeum brevisubulatum (Trin.) Link (barley).

\section{Zea mays (corn)}

Achillea millefolium $\mathbf{L}$. (common

yarrow).
Antennaria dioica (L.) Gaertn. (common pussytoes)

Anthriscus silvestris (chervil)

Arctous erythrocar pa Small. (redfruit ptarmiganberry)

Artemisia vulgaris L. sensu lat. (mugwort).

Asarum europaeum (wild ginger).... Atragene ochotensis Pall. (clematis).-

Chamaenerion angustifolium (L.) Scop. (fireweed).

Corydalis paeoniifolia (Steph.) Pers.

Cryptodiscts didymus

1.7 00093 Sagamu Bay, Japan ........ Fukai and Meinke (1962) $\ldots$ In dry matter, 0.00021 ppm.

.00015 Urayasa, Tokyo Bay,

\section{Fungi}

\begin{tabular}{|c|c|c|}
\hline $\begin{array}{r}11.6 \\
1.0 \\
1.0\end{array}$ & 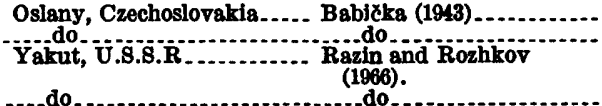 & $\begin{array}{l}\text { Ash, } 6.79 \text { percent. } \\
\text { Ash, } 6.51 \text { percent. } \\
\text { Ash, } 1.15 \text { percent. } \\
\text { Ash, } 0.4 \text { percent. }\end{array}$ \\
\hline Trace & Babicka (1943) & \\
\hline Trace & $\begin{array}{l}\text { (1966). } \\
\text { ia. ... Babicka (1943) }\end{array}$ & Ash, 0.60 percent. \\
\hline
\end{tabular}

\section{Whenens}

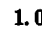

1.3

1.0

Yakut, U.S.S.R

Razin and Rozhkov

......do.

(1800)

do

\section{Mossee}

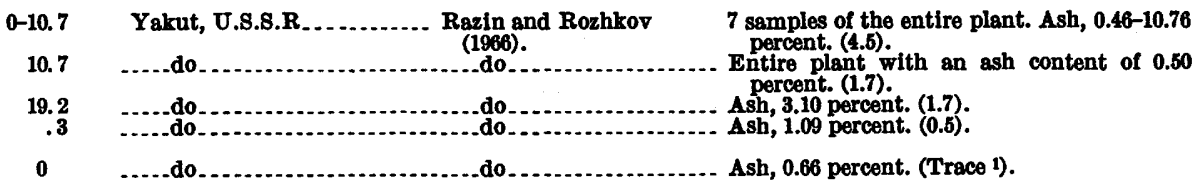

\section{VASCULAR PLANTS}

Herbs-Grasses and sedgee

.005

.003

.1-1.0

0-8. 6

$.006-.8$

$.06-2.4$

1

1. 5-2.

1.0

4. 36
.05

.003

10

1.0

$0-5$
Yakut, U.S.S.R

...-.do.

-....do.

......do.

do

do.

do.

do (1966).

. do.

do

2 samples of entire plant. Au in ppm, 0.7 and $8 \mathrm{sh}, 4.75$ and 0.80 percent, respectively. $(0.5)$. ntire plant with an ash content of 1.65 percent. (0.2).

2 samples of entire plant. $A u$ in ppm, 0.6 and 1.3 ; ash, 0.80 and 1.02 percent, respectively. (0.5)

samples of the entire plant. Ash, 0.46-10.76 percent. (4.5).

percent. (1.7).

Ash, 0.66 percent. (Trace 1$)$.

Razin and Rozhkov

$2^{\text {perc }}$
percent, 0. leaves, stems, and fruit. Ash, 3. 79 percent in sample containing 0.006 ppm Au. (0.5)

Stems, leaves, and fruit. Ash, 1.76 percent (0.2)

Gntire plant. Ash, 41.98 percent (probably in errur). (0.4).

samples of entire plant. Ash, in percent, $1.33-6.50$, average, 3.39. (4.5).

14 average, 3. 2. samples of entire plant. Ash, in percent, 17. 53, determined on 1 sample containing $0.9 \mathrm{ppm}$ Au. (2.5). Ash content of entire plant, 17.17 percent
(0.2).

Stem and leaves. Ash, 2.32 percent. (0.2).

\section{Herbe-Forbe}

Oslany, Czechoslovakia . .... Babicka (1943) _............ 3 samples.

Yakut, U.S.8.R ........... Razin and Rozhkov $\quad$ Ash, 2.0 percent. (0.2).

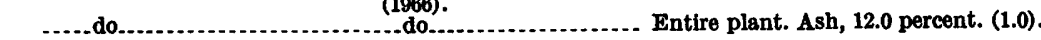

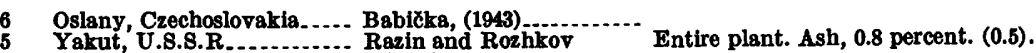

(1966).

Oslany, Czechoslovakia..... Babicka (1943) Yakut, U.S.S.R............ Razin and

$3.3 \quad \ldots$ do

1.5
Kyzyl-Kum, U.S.S.R do

Khotamov, Lobanov, and Kist (1966).
(4.5).

(4.5). 15 samples 13 samples of entire plant have 15 samples. 13 samples of entre plant have an Au coitent of 0-0.3 ppm and an ash content of 0.87-5.53 percent, which averages 2.4 percenti. 2 samples of entire plant except roots contain 5.0 and $4.6 \mathrm{ppm} A u$ and 0. and 0.31 percent ash, respectively. (8.0). samples. Entire

1.0 percent. (3.0). percent. For air-dried weight, the Au content, in ppm, is: seeds, 0.05; seed pods, 0.05 ; stems, 0.1 ; and roots, 0.05 . Analyses by neutron activation. ( $0.2 \mathrm{ppm}$ or less). 
TABLE 2.-Gold content of plants-Continued

\begin{tabular}{|c|c|c|c|c|}
\hline Organism & $\begin{array}{l}\text { Content in } \\
\text { ash (ppm) }\end{array}$ & Sampling locality & Reference & Remarks \\
\hline
\end{tabular}

\section{VASCULAR PLANTS-Continued}

\section{Herbo-Forbs-Continued}

Datusa stramontum (Jimson weed).. Equisetum sp. (horsetall)

Do.

Equisetum sp.

Do.

Do.

Equisetum aroense......................

Do.

Do.

Do.

Do.

Do

Do

Do...

Do

Do...

Do.

Do.

Equisetum hyemale var. robustum

Equisetum limosum.

Do

Equisetum littorale.

Equisetum palustre $\mathrm{L}$.

Do.

Equisetum pratense Ehrh.

Do

Do

Equisetum sylvaticum.

Do

Equisetum variegatum

Erigeron flacetdus Botsch.

Iris setosa Pall. (Aretic iris) .......... Leucofum aestioum $\mathrm{Z}$ wiebel (summer snowfiake).

Linnaea borealis I. (twinflower)......

Lycopodium anceps Wallr. (clubmoss).

Lycopodium annotinum

Lycopodium clavatum L..........................

Maianthemum bifolium (L.) Fr.

Schmidt (twoleaf beadruby).

Mentha aroensis (corn mint)

Nardosmia frigida (L.) Hook.........

Paris quadrifolia var. obovata Ldg -... Pedicularis labradorica Wirsing........ Pyrola incarnata Fisch Palsola arbusculiformis $\mathbf{\text { P................. }}$
20.2

Gross Bchũttinsel, Crecho- Bablcka (1943)

.34 North Fork of Watson Bar Warren and Delavault Creek, British Columbia, (1950). Canada.

.17

.33

.2

.12

.1

$<.1$

.1

.1

.1

.1

.1

.2

.2

.4

16

63

${ }^{63} 4$

do..............

Cannon, Shacklette, and Ash, 16.5 percent.

do Ash, 15.1 percent. Plant from muskeg.

Yakut, U.S.S.R.

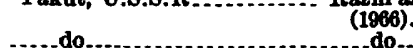

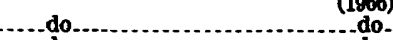

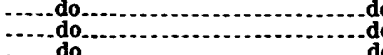

Kyzyl-Kum, U.s.s.R...... Khotamov, Lobanov, and Kist (1966).

\section{Cannon, shacklette, and} Bastron (1968). do.

do.

Razin and Rozhkov 1966).

2

Ash, 2.34 percent. (0.6).

Ash, 16.70 percent. Plant was sampled from an $\operatorname{au}$

Ash, 17.20 percent. Plant sampled from an auriferous area with an overburden of 4-8 ft. Ash, 18.00 percent. Plant sampled from an auriferous area with an overburden of $4-8$ at.

sh, 22.75 percent. Plant sampled from an auriferous ares with an overburden of 4-8 ft. Ash, 30.7 percent.

Ash, 33.7 percent. Plant on tallings from ore. Ash, 29 percent. Plant near shait on undisAsh, 35.9 percent. Plant on tailings.

Ash, 33.2 percent. Plant on outcrop of schist.

Ash, 18.6 percent. Plant on limestone mine dum, 21 percent.

Ash, 22.6 percent. Collected over schists.

Ash, 18.9 percent. Plant below upper tailings Ash 28.4 percent. Plant on alluvium below Black Cat mine.

Ash, 29.2 percent. Plant growing above quartz

Veins.
Ash, 14.8 percent. Plant from muskeg. Ash, 24.6 percent. Plant in ravine by mercury (0.2). Ash, 14.1 percent. Plant from lake fed by drain from abandoned mercury mine.
Ash, 33.3 percent. Plant on mill tailings.

Ash is 61.20 percent sillica. See Mentha arvensis. (0.2).

2 samples of entire plant. Ash, 5.5 and 2.2 percent, respectively. (1.7).

4 samples of entire plant. Oniy 1 sample with detectable Au. Ash, in percent, 2.41-9.63, average 7.5. (2.4).

Ash, 24 percent. Plant on river alluvium below mill.

Ash, 38.2 percent.

Ash, 13.2 percent. Plant from muskeg.

Ash, 14.5 percent. Plant from loess near mercury mine. 27.1 percent.

Ash, 3.52 percent. (Trace 1.)

Stems and leaves. Ash, 2.18 percent. (0.2). (0.6).

4 samples. Entire plant. Ash, in percent: 9.81-11.0, average, $10.3(4.5)$. samples. Ash, in percent, 4.22 and 5.00 , respectively. (0.3).

Ash, 4.00 percent for entire plant. (1.9). Ash, 28.02 percent (probably in error) for entire plant. (4.0). Leaves. Ash, 7.03 percent. (0.3).

Sampled from the same place as an Equisetum palustre which contained $610 \mathrm{ppm} A \mathrm{u}$ in the ash. (0.2).

Entire plant. Ash, 6.13 percent. (Trace 1.)

Stems and leaves. Ash, not determined. Entire plant. Ash, 10.17 percent (Trace. 1) Entire plant. Ash, 0.47 percent. (0.5).

rom a fresh plant with an ash content of 9.5 percent. For alr-dried weight the Au content, in $\mathrm{ppm}$, is: leaves, 0.05; terminal stems, 0.15; and main stems, 0.1. Analyses by neutron activation. (0.2 ppm or less).

From a fresh plant with an ash content of 20 percent. For air-dried weight the Au content, in $\mathrm{ppm}$, is: leaves, 0.02; terminal stems, 0.1 ; main stems, 0.2 ; and roots, 0.05 . Analyses by neutron activation. (0.2 ppm or less). 
TABLX 2.-Gold content of plants-Continued

\begin{tabular}{|c|c|c|c|c|}
\hline Organism & $\begin{array}{l}\text { Content in } \\
\text { ash (ppm) }\end{array}$ & Sampling locality & Reference & Remarks \\
\hline
\end{tabular}

\section{vascular pLaNTs-Continued}

Herbo-Forbe-Continued

Salsole rigida (Russian thistle)......

Sanguisorba officinalis $\mathbf{L}$

Tanacetum vulgare $\boldsymbol{L}$. (common tansy).

Trifolium pratense L. (red clover) ... Urtica sp. (nettle) Veratrum oxysepalum Turcz. (falso hellebore).

Alnus fruticosa Rupr. (Manchu alder).
1.2
16.8

1.7

1.5

0-1.98
Kyzyl-Kum, U.S.8.R....... Khotamov, Lobanov, and Kist (1966).
Rasin and Rozhkov (1966).
From a nearly dry plant with an ash content of 18.0 percent. For air-dried weight the $A v$ content, in ppm, is: leaves, 2.4; terminal stems, 0.05 ; main stems, 0.02 ; and roots,
0.02 . Analyses by neutron activation. $(0.2$ 0.02. Analyses

ppm or less).
Entire plant. Ash, 2.4 percent. (0.2).

5 samples. Entire plant has 0 and $0.4 \mathrm{ppm}$ Au and an ash content of 4.0 and 7.8 , respectively; except roots but including thowers, the Au, content is $1.86 \mathrm{ppm}$, and the ash content, 1.2 percent. The Au content of flowers is $0.6 \mathrm{ppm}$, and the ash content, 6.71 percent. Stems and leaves contain no detoctable Au and had an as Entire plant. Ash, 6.67 percent. (Trace.) 1

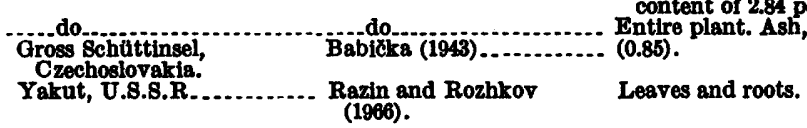

\section{Shrube}

0-.9 Yakut, U.S.S.R.......... Razin and Rozhkov (1966).

28 analyses, ash, 0.3-3.76 percent. 19 analyses of branches with leaves; $\mathrm{Au}, 0-0.08 \mathrm{ppm}$, ash 0.7-3.76 percent. (1.9). 7 analyses of branches only; Au, 0-0.005 ppm, ash, 0.3-1.5 percent. (3.4). 1 analysis of a seed capsule; $A$ u 0.0 ppm and ash 0.91 percent. (4.5). 1 anglysis of young shoots with leaves and seod capsules; Au, 0.4 ppm and Ash, 0.35 percent. (3.2).

Clematis vitalba (virgin's bower)......

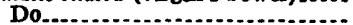

Do

Do.

Corvlus aveliana (hazel nut, filbert)

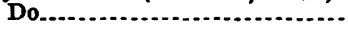

Do

Cousinia hamadae.

Dasiphora fruticosa (bush cinquefoil).

Empetrum nigrum (crowberry) ......

Girgensohnia oppositiflora.

600

50

7
110

110
Trace
$6-9$

20 1.0

1.2

0-2.5

2.1 Haplophylum robutum (golden-
weed).

Juniperus communis (common Juniper).

Do

Do

Lagochilius intermedius

Ledtum palustre L. (crystal tea).....

Yakut, U.S.S.R Razin and Rozhkov (1966).

Czechoslovakia.

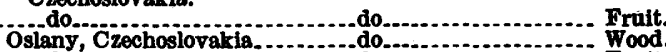

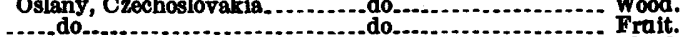

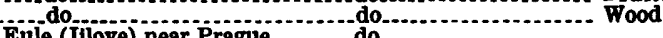

Eule (Jilove) near Prague, .....do.....................

Czechoslovakia. $\mathbf{K}$ yzyl-Kum, U.s.s.R........
and Kist (1966).

Yakut, U.8.8.R

Razin and Rozhkov

(1966).

Kyzyl-Kum, U.s.S.R and $K$ ist (1966).

11. 4

$<0.03$ Creek, British Columbia, (1950).

Nil Canada. ..do.

$61 \quad \ldots 1 . .$. do

do. Kist (1966).

Oslany, Czechoslovakia...... Babicka (1943) ........... Seeds.
Eule (Jilove) near Prague,

Khotamov, Lobanov,

North Fork of Watson Bar Warren and Delavault

Sampled from an old gold mine dump(?).

From a dry plant with an ash content of 13.0 percent. For air-dried weight the Au content in ppm is: leaves, 0.05 ; upper twigs, 0.05 ; stems, 0.05 ; and roots, 0.05 . Analysis by neutron activation. ( $0.2 \mathrm{ppm}$ or less).

Entire plant except roots. Known also as

Potentilla fruticosa L. (0.5)

5 samples of entire plant. Ash, 0.4-2.88 percent. (4.0).

From a dry plant with an ash content of 20.0

percent.- For air-dried weight, the Au percent. in ppm, is: leaves, 0.26; terminal stems, 0.05; and main stems, 0.05. Analyses by neutron activation. (0.2 ppm or less). by neutron activation. (0.2 ppm or less).
From a fresh plant with an ash content of From a fresh plant with an ash content of content, in ppm, Is: leaves, 0.6 ; terminal stems, 0.05; main stems, 0.05 ; and roots, 0.02 . Analyses by neutron activation. (0.2 ppm or less).

4 composite samples. Dry matter is 4.10 percent ash.

3 composite samples. Dry matter is 4.68 percent ash.

From an auriferous area with an overburden of 4-8 ft. Ash, 3.25 percent (Trace).

36 Kyzyl-Kum, U.S.S.R...... Khotamov, Lobanov, and

rom a fresh plant with an ash content of 15.0 percent. For air-dried weight the Au content, in ppm, is: seeds, 0.025 ; seed pods, 0.5 ; lesves, 3.0 ; terminal stems, 0.5 ; main 0.5; leaves, 3.0; terminai stems, stems, 0.2 ; and roots, 1.0 . Analyses

activation. (0.2 ppm or less).

39 samples. Ash, 0.34-2.53 percent. 29 samples of entire plant; ash, 0.42-2.53 percent, $\mathrm{Au}$, $0-1.6 \mathrm{ppm}$ in ash. (2.0). Stems, 6 samples; ash, 0.34-1.51 percent, Au, 0-4.2 ppm in ash. (4.1). Stems with leaves; ash, 0.34 and 1.0 percent, $A \mathbf{n}, 0.3$ and $1.0 \mathrm{ppm}$ in ash respectively. (2.5). Young shoots with leaves and seeds; ash, 1.5 percent, Au, 3.6 ppm in ash. (4.7). Roots; ash, 1.52 percent. Au, $6.0 \mathrm{ppm}$ in ash. (4.1).

6 samples with ash from $1.54-7.89$ percent. 5 samples of stems, branches, and leaves; ash, 1.54 89 percent 40 , 5 ppm; ash, 1.01-7.89 porcont, $\mathrm{Au}$, ppm.

do.

Lonicera altaica Pall. (honeysuckle)- 
TABLE 2.-Gold content of plants-Continued

\begin{tabular}{llcc}
\hline Organism & $\begin{array}{l}\text { Content in } \\
\text { ash (ppm) }\end{array}$ & Sampling locality & Reference \\
\hline
\end{tabular}

\section{VAsCULAR PLants-Continued}

\section{Shrube-Continued}

Nanophyton erinaceum

Ribes procumbens Pall, (gooseberry). Rosa acicularis Lindl. (prickly rose).
0.3

Trace 1 Yakut, U.8.S.R 0-2.2
Kyzyl-Kum, U.S.S.R.

Razin and Rozhkov (1966).

Rosa canina (dog rose)

Rubus arcticus L. (Arctic bramble).. Rubus sachalinensis Levl.

Rubus saxatilis L. (stone berry)..... Salix sp. (willow) .........................

Do

Salix caprea $\mathrm{L}$

Salix floderusii Nakai

Salix kolymensis $\mathrm{O}$. V. Seem.

Salix pentandra $\mathbf{L}$

Salix viminalis $\mathbf{L}$ Salix xerophila Floder

Sorbus sibirica Hedl

Spiraea media (Fr.) Schmidt (oriental spirea).

Vaccinium myrtillus L. (bilberry, blueberry)

Vaccinium uliginosum L. (bog bilberry).

Vaccinium vitis-idaea L. (cowberry).

do

Razin and Rozhkov (1966).
$0-2.8$
i. 02 ....do
do
North Fork, Watson Bar Warren and Delavaul Creek, British Columbia, (1950).
Canada.

\begin{tabular}{|c|c|c|}
\hline $\begin{array}{l}0, .03 \\
0-.005\end{array}$ & Yakut, U.S.S.R & $\begin{array}{l}\text { Razin and Rozhkov } \\
\text { (1966). }\end{array}$ \\
\hline O & _...do... & ...do. \\
\hline
\end{tabular}

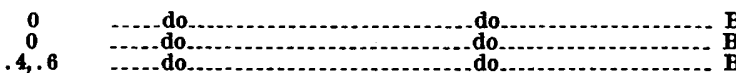

0
$0,0.2$

(1).

.6 Kuznetsk Ala-Tau,

U.s.s.R

0-1.7

Zryagintzev (1941)
Razin and Rozhkov (1966).

\section{Trees}

Betula fruticosa Pall. (Altai birch).

Betula hybrida Schneld

0-2.5

0-1. 3

$05-.26$
Betula middendorffii Trautv. et Mey. (Middendorf birch).

Betula platyphylla Sukatch. (Asian white birch).

Diptychocarpus strictus (Gurjunoil tree). Kist (1966). From a dry plant with an ash content of 16.0
percent. For air-dried weight the Au content, in ppm, is: leaves, 0.05 ; terminal stems 0.05 ; main stems, 0.05 ; and roots, 0.05 . Analyses by neutron activation. $(0.2 \mathrm{ppm}$ or less).

Branches. Ash, 1.09 percent. (0.5).

16 samples with an ash content of $0.6-3.88$ percent. 10 sample $s$ of the entire plant; ash 1.0-3.89 percent, Au, 0-2.2 ppm in ash. (1.2). 3 samples of entire plant without berries: ash, 0.8-2.25 percent, $A u, 0.04-0.2 \mathrm{ppm}$ in ash. (1.9). Berries, ash, 2.64 percent, Au 0 ppm. (4.5). Plant at surface(?) of ground $0 \mathrm{ppm}$. (4.5). Plant at surface(?) of ground; ppm in ash, respectively. (8.0).

3 analyses. Entire plant, ash, $0.73-4.4$ percent. (4.5)

6 analyses. Entire plant, ash, 1.1-7.03 percent. (6.0).

Entire plant. Ash, 7.5 percent. (1.9).

Ash, 2.20 percent. From an auriferous area with an overburden of 4-8 $\mathrm{ft}$.

2 samples. Ash, 6.36 percent. From a nonauriferous area.

2 samples of branches with leaves. Ash, 2.25 percent. (4.5).

2 samples of branches with leaves. Ash, 0.8 and 1.83 percent. $(0.2)$.

Branch with leaves. Ash, 1.86 percent. (0.2).

12 samples. Ash, 0.82-4.72 percent. 9 samples of branches with leaves; ash 1.41-4.72 percent, Au, 0-trace in ash. (0.5). 3 samples of branches without leaves; ash, 0.82-1.92 percent, $\mathrm{Au}, 0-0.06 \mathrm{ppm}$ in ash. $(0.5)$

Branches with leaves; ash, 5.6 percent (0.2) Branches with leaves; ash, 1.93 percent $(0.6)$ Berries; ash, 5.62 percent, $0.4 \mathrm{ppm}$ in ash. (1.9). Branches and leaves; Au, 0.6 ppm in ash. (1.9).

Entire plant. Ash, 1.9 percent. (0.2).

Ash, 4.19 and 10.5 percent, respectively. En-

tire plant: (1.9).
18 samples. Ash, 0.6-3.0 percent. 14 samples of the entire plant; ash, 0.6-3.0 percent, $\mathbf{A u}$, $0-0.2 \mathrm{ppm}$ in ash. (4.5). Stems and branches ash, 0.65 and 0.82 percent, $A u, 0$ and 0.00 ppm in ash, respectively. (Trace '). Stems and roots; ash, 1.0 percent, Au, $0.3 \mathrm{ppm}$ in ash, (1.9). Stems, branches, and leaves; ash 0.7 percent, $A u, 4.6 \mathrm{ppm}$ in ash. (3.2).

17 samples of entire plant; ash, $0.7-4.59$ percent, Au, 0-0.8 ppm in ash. (2.5). Berries, Au, $0.7 \mathrm{ppm}$ in ash. (0.5).

\section{Trunk and branches $1 \mathrm{~m}$ apart.}

2 samples. Ash, in branches, 0.73 percent. in branches and leaves, 1.82 percent. $(0.5) \mathrm{s}$ 17 samples. Ash, 0.5-2.33 percent. 8 sample; of branches with leaves; ash, 0.5-2.2 percent, Au 0-1.7 ppm in ash. (3.2). 7 samples of branches; ash, 0.5-2.33 percent, Au 0-0.005 ppm in ash. (3.4). 2 samples of leaves; ash, 2.2 and 2.33 percent, Au 0.1 and $0 \mathrm{ppm}$ in ash, respectively. (2.4).

17 samples. Ash, 0.5-3.95 percent 11 samples of Au 0-2.5 ppm in ash. (4.0). Branch, Au 0-2.5 ppm in ash. (4.0). Branches, 6 samples; ash, 0.5-0.91 percent, Au 0-0.005 ppm in ash. (2.5)

samples. 6 samples of branches with leaves; ash, 0.96-3.24 percent, Au 0-1.3 ppm in ash. (4.5). Ash in leaves, 1.86 percent, Au in ash, $0.1 \mathrm{ppm}$. (Trace 1)

From a dry plant with an ash content of 20.0 percent. For air-dried weight, the Au content, in ppm, is: leaves, 0.26; terminal stems, 0.05; and main stems, 0.05 . $(0.2 \mathrm{ppm}$ or less). 
in soil on which the mosses grew (given in parenthesis) was generally less than the amount of gold found in the ashes of the plants.

\section{HERBS}

The herbs include the largest variety of plants sampled for gold. Many replicate analyses have been made for some species. The herbaceous plants are shown to contain gold which ranges, in their ash, from 0 to $610 \mathrm{ppm}$. The extremely high value-the highest value known to be reported for a plant-was given by Babička (1943) for the marsh horsetail, Equisetum palustre which grew in the gold-mining region of Oslany, Czechoslovakia, where the gold content of the soil was reported to be only $0.2 \mathrm{ppm}$. In the ash from two other specimens of Equisetum arvense, Babička detected 16 and $63 \mathrm{ppm}$ gold. Because of the possibility that species of Equisetum may be accumulators of gold, Cannon, Shacklette, and Bastron (1968) examined 22 collections of these plants that were gathered throughout the United States. From their analyses of these plants, they concluded that the average amount of gold to be expected in this vegetation is less than $0.2 \mathrm{ppm}$ and consequently Equisetum would not be useful in prospecting for gold. In addition they noted that the high values of $610 \mathrm{ppm}$ gold in the ash of $E$. palustre and $63 \mathrm{ppm}$ gold in the ash of $E$. arvense may be erroneous due to the probability, in the original analyses, that the sulfides of copper and several other metals were reported as gold. Other workers have reported about the same amounts of gold in the ash of Equisetum as found by Cannon, Shacklette, and Bastron. For instance, Warren and Delavault (1950) reported from 0.17 to $0.34 \mathrm{ppm}$ (average $0.3 \mathrm{ppm}$ ) gold in the ashes of four plants, and Razin and Rozhkov (1966) reported from 0 to $0.7 \mathrm{ppm}$ gold in the ashes of six plants.

In the ashes of the forbs, Babicka reported gold contents of $4.36 \mathrm{ppm}$ and more. By comparison, the average amount of gold in the ashes of forbs as reported by other workers who succeeded Babicka rarely exceeded the minimum amount reported by him.

Although differences in the gold content of various parts of plants were observed, no plant part appeared to be superior to any other part in its amount of gold. The parts compared were roots, main and terminal stems, leaves, flowers, seeds, and seed pods.

The amount of gold in the plant ash reported by Babička greatly exceeded the gold content of the soil. However, other workers (Khotamov, Lobanov, and Kist, 1966, and Razin and Rozhkov, 1966) show much smaller differences. Many plant ashes contained less gold than the soil in which they grew (table 2).

There appears to be no significant differences in the gold content of forbs and of grasses and sedges. The gold content in the ashes of grasses and sedges ranged from 0 to $8.6 \mathrm{ppm}$. The maximum gold content of the soil was $8 \mathrm{ppm}$.

As a gold-sampling device of the flowering plants in a neighbourhood, honey has been analyzed for gold by Berg (1928) but without success.

\section{SHRUBS}

The amount of gold in the ashes of shrubs varied from 0 to $600 \mathrm{ppm}$. Excluding the amounts reported by Babicka, the maximum amount was $36 \mathrm{ppm}$ given by Khotamov, Lobanov, and Kist (1966) who used neutron-activation methods of analyses for plants.

Khotamov, Lobanov, and Kist (1966) analyzed the separate parts of a few shrubs (table 2). More gold was detected in the leaves of Girgensohnia oppositiflora, Haplophyllum robustum, and Lagochilius intermedius than in their roots, terminal stems, or main stems, but in Nanophyton erinaceum the same amount of gold was reported for these various parts.

Razin and Rozhkov (1966) reported a maximum gold content for the ash of shrubs as $10 \mathrm{ppm}$ (Rubus arcticus) and the maximum gold content of the soil, $4.5 \mathrm{ppm}$. Near some other shrubs the maximum gold content of the soil was $8 \mathrm{ppm}$. They found in about two-thirds of the soil and plant samples analyzed that the maximum amount of gold in the soil exceeded that in the ashes of shrubs.

TREES

The gold content of trees is similar to that of other vegetation. The amount of gold reported in tree ashes varies from 0 to $10 \mathrm{ppm}$, the high amount being reported by Babička (1943) for the ash from the blossoms of Tilia parvifolia. Gold was not detected in the ashes of a variety of trees. No tree part was shown to be consistently higher in gold content than any other part. According to the analyses of Razin and Rozhkov (1966), the maximum amount of gold found in the soil near the analyzed trees was usually greater than the gold in the ashes of the adjacent plants.

\section{SUMMARY}

The maximum amount of gold that has been reported in the ash of plants is $610 \mathrm{ppm}$ (Babička, 
1943). However there is serious doubt regarding the reliability of some of the values reported by Babička; probably the reported maximum amount of gold in plant ash is much less. The maximum values given in table 2 by other investigators for gold in the ash of some terrestrial vegetation is: Cannon, Shacklette, and Bastron (1968), 0.5 ppm; Warren and Delavault (1950), $1.02 \mathrm{ppm}$; Razin and Rozhkov (1966), 19.2 ppm; Khotamov, Lobanov, and Kist (1966), $36 \mathrm{ppm}$; Zvyagintzev (1941), $6 \mathrm{ppm}$; Lungwitz (1899), $0.15 \mathrm{ppm}$; and Stark (1943), $1.7 \mathrm{ppm}$. At present the amount of data is insufficient to show that one part of a plant contains more gold than any other part, although a few analyses by Khotamov, Lobanov, and Kist (1966) suggest the possibility that leaves may contain more gold than other plant organs. In addition no group of plants seems to contain consistently more gold than any other group.

Razin and Rozhkov (1966) found that the maximum amount of gold in the soil (usually the C horizon) exceeded that shown for the ash of most of the plants which they analyzed. However Khotamov, Lobanov, and Kist (1966) believe that "the concentrations of gold in plants exceeds considerably the gold content in the soil." Analyses of the gold content of mull (humus-rich forest soil) ash that was derived chiefly from lodgepole pine (Pinus contorta), limber pine (Pinus flexilis), and aspen (Populus tremuloides) in the Empire mining district of Colorado was, with few exceptions, higher than that in the underlying soil (Curtin and others, 1968). Although the concentrations of gold in the ash of plants generally appear to exceed the gold content of the soil, the differences between the gold content of the ash of plants to that of the earth's crust and various rock types appears to be much greater. Based on neutron-activation analyses, the gold content of igneous rocks is given as $3.6 \mathrm{ppb}$, for sedimentary rocks, $5.4 \mathrm{ppb}$, and for metamorphic rocks, $4.6 \mathrm{ppb}$ (Jones, 1969), and for the earth's crust, 1 to $6 \mathrm{ppb}$ (Jones, 1968). Probably, then, the amount of gold in plant ash may be one or more magnitudes higher than the amount found in the rocks in the earth's crust.

\section{GOLD CONTENT OF ANIMALS}

Gold has been looked for in only a few animals. Known analyses have been made on four different types of insects, seven different types of marine organisms, and seven types of warm-blooded animals.
Cockchafers (scarabaeid beetles) have been found to be auriferous when indigenous to Oslany, a gold-mining region in Czechoslovakia, but not when from the region of Propast near Stribrna Skalica (Bohemia). The gold content of cockchafers can be reduced by feeding them nonauriferous plants (Babička, Komárek, and Némec, 1945). Razin and Roshkov (1966) looked for but did not detect gold in the water beetle (Dytiscus sp.) or in the carpenter ant (Camponotus vagus), although $0.4 \mathrm{ppm}$ gold was obtained from the ash of a bee (Vispidae sp.).

The amount of gold found in some marine animals is shown in table 3 . Analyses made by neutron activation are much lower than those made by older methods. For instance, Noddack and Noddack (1939) reported from 7 to $30 \mathrm{ppb}$ gold in the dry matter of several marine animals. By contrast values obtained by neutron-activation methods vary from 0.0012 to $0.126 \mathrm{ppb}$ gold in the dry material (Fukai and Meinke, 1962; Bowen, 1968; Oka, Kato, and Sasaki 1964). The least amount of gold was found in the dry matter of the muscle of the mackerel, Pneumatophorus japonicus. Bowen (1968) reported $0.126 \mathrm{ppb}$ gold in the dry matter of a sponge from Plymouth, England (table 3). He thought that this value was due to the relatively high initial gold content of sea water in the area where the sponge grew and to the scleroprotein structure of the sponge which resembles some artificial polymers. According to Bowen, gold can be concentrated by absorption or adsorption on certain artificial polymers. In the dried matter of fishes, Fukai and Meinke (1962) found $0.1 \mathrm{ppb}$ gold in the soft parts. This was considerably more gold than was found in the soft parts of the mackerel Pneumatophorus japonicus by Oka, Kato, and Sasaki (1964). The average amount of gold in the dry matter of marine organisms seems to be about the same as that which occurs in sea water. This conclusion is based on neutron-activation methods of analysis for both. The figures used in computing the average gold content of marine animals are taken from table 3 , and, in addition, include the $0.1 \mathrm{ppb}$ gold reported by Fukai and Meinke (1962). This average is $0.04 \mathrm{ppb}$ and is close to that of $0.05 \mathrm{ppb}$ for sea water. The values given for comparison are obviously based not only on too few analyses but are also probably not representative of their kind.

Gold has been detected in birds, cows, deer, and man and has been administered to laboratory animals such as rats and mice. Gold was looked for 
TABLE 3.-Gold content of marine animals

[See table 2 for comparison with the marine plant, Uloa sp.]

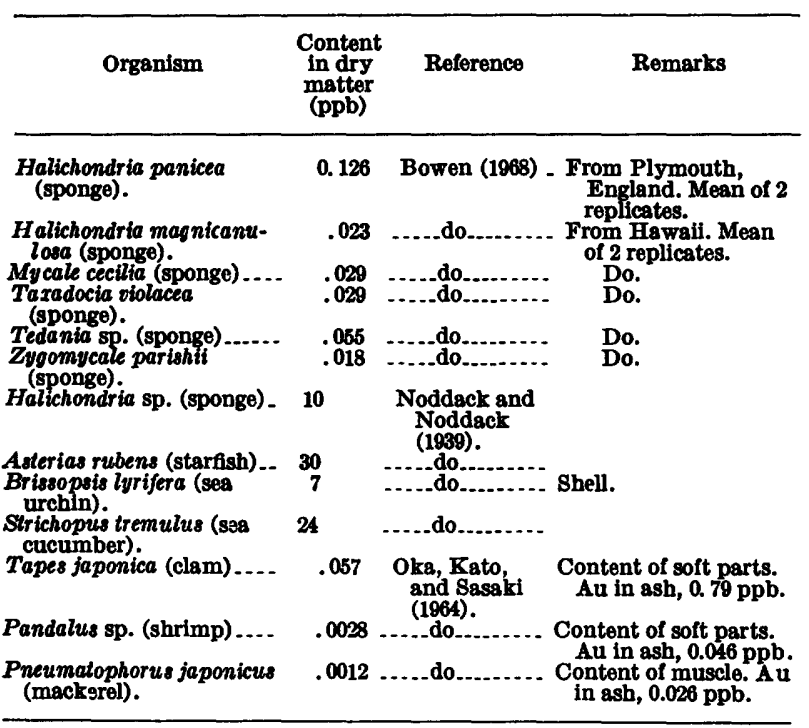

but not detected in the bones and teeth of a wild pig shot in the gold-mining region of Oslany, Czechoslovakia (Babička, 1943).

A number of birds were examined for gold by Razin and Rozhkov (1966). These consisted of three northern spruce crossbills, Loxia curvirostra curvirostra $\mathrm{L}$., which contained from no detectable gold to $1.1 \mathrm{ppm}$ in their ash (2.43 to 2.80 percent), four Siberian white crossbills, Loxia leucoptera bifasciata Brehm., which contained from no detectable gold to as much as $1.5 \mathrm{ppm}$ in their ash (2.36 to 2.75 percent), one common bunting, Emberiza leucocephalos Gm., which contained $1.2 \mathrm{ppm}$ in its ash (4.13 percent), two unidentified buntings, Emberiza, which contained no detectable gold in one ( 3.67 percent ash) and $0.3 \mathrm{ppm}$ gold in the other (3.61 percent ash), three Siberian spotted pipits, Anthus hodgsoni inopinatus Hart. et Steinb., which contained from 0.1 to $0.9 \mathrm{ppm}$ gold in their ash (4.83 to 6.15 percent), and one redwing thrush, Turdus naumanni naumanni Temm., which contained $0.1 \mathrm{ppm}$ gold in its ash (1.64 percent).

Antlers from deer harvested in Czechoslovakia and in the United States have been analyzed for gold. Babička, Komárek, and Némec (1945) analyzed different parts of the roebuck from Oslany, Czechoslovakia, a gold-bearing region. They found gold in the ashes of the hair of the roebuck, from 3 to $8.5 \mathrm{ppm}$ and an inconsiderable amount in the hooves, but most in the ash of the antlers, 60 ppm in one animal and $68 \mathrm{ppm}$ in another animal. The points of the antlers contained the most gold. No gold was found in the antlers of deer shot in the eastern Carpathian Mountains or near Karlstein. By contrast, the antlers of $\mathbf{1 5}$ mule deer (Odocoileus hemionus), harvested from four gold-mining regions in the United States (in the mother lode country, California, near Ouray, Colo., Lead, S. Dak., and Eureka, Utah), contained about the same amount of gold in their ashes as occurs in relatively nonauriferous rocks (Jones, 1969). Neutron-activation analyses were made by members of the U.S. Geological Survey on the 1- and 1/4-inch-long tips of the antlers of these deer. The amount of gold found in the ashes of the 1-inch-long tips ranged from 0.5 to $6.4 \mathrm{ppb}$ and averaged $2.3 \mathrm{ppb}$. In the ashes of the $1 / 4$-inchlong tips from five of these deer, the amount of gold detected ranged from 0.3 to $28.3 \mathrm{ppb}$ and averaged $7.0 \mathrm{ppb}$. Thus it seems that more gold, per unit volume, occurs at the very tips of the antlers.

Gold has been found in cow liver and brains, and in human blood, feces, and urine (Bertrand, 1932). Bertrand detected $0.3 \mathrm{ppm}$ gold in human blood, $0.2 \mathrm{ppm}$ in cow liver, but most of all, the brain of an ox yielded $14 \mathrm{ppm}$ which indicates a high value for brains. The amount of gold in 32 samples of wet human liver tissue ranged from 0.03 to $0.79 \mathrm{ppb}$ and averaged $0.057 \mathrm{ppb}$ (Parr and Taylor, 1963). In human blood the mean gold content is about $0.004 \mathrm{ppb}$, in erythrocytes about $0.008 \mathrm{ppb}$, and in plasma, about $0.006 \mathrm{ppb}$ (Bagdavadze and others, 1965). The amount of gold in whole normal and uremic human bloods was found to be the same (Aripova and Prikhid'ko, 1965). The amount of gold detected in human hair varied from 0.8 to $430 \mathrm{ppb}$ (Bate and Dyer, 1965), the amount of gold in the hair of a man from Napier, New Zealand, averaged $270 \mathrm{ppb}$ and from Hastings, New Zealand, $290 \mathrm{ppb}$. The average amount of gold in the hair of a man from Tennessee was $430 \mathrm{ppb}$. The amount of gold found in human teeth ranges from 10 to $30 \mathrm{ppb}$ dry weight (Soeremark and Samsahl, 1962; Lundberg and others, 1965). Although no significant differences could be noted in the gold content of teeth on the basis of sex or between the upper or lower jaws, unerupted (impacted) bicuspids contained no detectable gold.

Gold has been administered to rats and mice and the effects noted. The administration of gold thioglucose to mice results in a focal accumulation of gold in the hypothalamus (Debons and others, 1962). Gold given to white rats by Kalistratova, Moskalev, and Serebryakov (1966) resulted in an accumulation of some of the gold 
mainly in the liver, spleen, and lymphatics. Katakura (1965) noted that gold administered intravenously in colloidal form in rats concentrated chiefly in the liver and spleen and less was retained in the lungs, kidneys, and femoral bones.

\section{SUMMARY}

The amount of gold occurring in animals varies greatly. Values obtained by neutron activation show as little as $0.0012 \mathrm{ppb}$ gold has been found in the dry matter of fish muscle and as much as $430 \mathrm{ppb}$ gold in human hair. Excluding the earlier work of Noddack and Noddack (1939), marine animals contain, by far, the least amount of gold and terrestrial animals contain the most gold. Bones, teeth, and phosphorite are calcium phosphates with comparable gold contents. Neutronactivation analyses of composite samples of rock phosphorites from Morocco and the United States contained from 0.5 to $3.1 \mathrm{ppb}$ gold (Z. S. Altschuler, oral commun., 1969), human teeth show 10 to $30 \mathrm{ppb}$ gold, and the ash of deer antlers from 0.5 to $28.3 \mathrm{ppb}$ gold. These naturally occurring calcium phosphate compounds appear to be similar in their gold content, irrespective of their origin, and probably reflect the gold level of their environment.

The known content of gold in animals apparently supports Vinogradov's (1953) observation that the amount of gold found in animal organs is entirely casual and that there are no auriferous animals anywhere in the world.

\section{REFERENCES CITED}

Aripova, Kh., and Prikhid'ko, P. L., 1965, Determination of gold in plants and soils during biogeochemical studies: Akad. Nauk Uzbek. SSR Uzbek. Geol. Zhur., v. 9, no. 4, p. 50-53 (in Russian).

Aripova, Kh., and Talipov, R. M., 1966, Features of the concentration of gold in soils and plants of the southern part of Tamdynsk Mountain: Akad. Nauk Uzbek. SSR Uzbek. Geol. Zhur., v. 10, no. 3, p. 45-51(in Russian).

Babička, J., 1943, Gold in living organisms: Mikrochemie verein Mikrochim. Acta, v. 31, p. 201-253 (in German).

Babička, J., Komárek, J. M., and Némec, Bohumil, 1945, Gold in animal bodies: Acad. Tcheque Sci. Bull. Internat., Cl. Sci. Math., Nat. et Med., v. 45, chap. 13, p. 1-7.

Bagdavadze, N. V., Barbakadze, L. V., Ginturi, Kuchava, Mosulishvili, L. M., and Kharabadze, N. E., 1965, Radioactivation method for determination of gold in blood: Akad. Nauk Gruzin. SSR Soobshch., v. 39, p. 287-294 (in Russian).

Bate, L. C. and Dyer, F. F., 1965, Trace elements in human hair: Nucleonics, v. 23 , no. 10, p. 74-81.
Becker, G. F., 1888, Geology of the quicksilver deposits of the Pacific slope: U.S. Geol. Survey Mon. 13, $486 \mathrm{p}$.

Berg, Ragnar, 1928, Das allgemeine Vorkommen von Gold in Nahrungsmitteln und Organen: Biochem. Zeitschr., v. 198, p. 424.

Bertrand, Gabriel, 1932, Peut-on compter l'or parmi les éleménts de la matière vivante?: Soc. Chim. France Bull., v. 51, p. 564-568.

Bouska, Vladimir, Havlena, Vaclay, and Sulcek, Zdenek. 1963, Geochemistry and petrography of the Cenomanian coals from Bohemia and Moravia: Československá Akad. Vèd Răda, matematicky̆ch a płrirodních Věd., v. 73, no. 8, p. 3-78 (in Czech)

Bowen, H. J. M., 1968, The uptake of gold by marine sponges: Marine Biol. Assoc. United Kingdom Jour.: v. 48 , no. 2 , p. 275-277.

Caldwell, W. E., 1938, Gold content of sea water: Jour. Chem. Education, v. 15, p. 507-510.

Cannon, H. L., Shacklette, H. T., and Bastron, Harry, 1968, Metal absorption by Equisetum (horsetail): U.S. Geol. Survey Bull. 1278-A, 21 p.

Claude, Georges, 1936, Sur la présence de l'or dans l'eau de mer: Acad. Sci. Comptes Rendus, v. 202, p. 1885-1887.

Coates, J. E., 1939, The Haber memorial lecture: Chem. Soc. [London] Jour., 1939, p. 1642-1672.

Curtin, G. C., Lakin, H. W., Neuerburg, G. J., and Hubert, A. E., 1968, Utilization of humus-rich forest soil (mull) in geochemical exploration for gold: U.S. Geol. Survey Circ. 562, 11 p.

Debons, A. E., Silver, Lawrence, Cronkite, E. P., Johnson, H. A., Brecher, George, Tanzer, Doris, and Schwartz, I. L., 1962, Localization of gold in mouse brain in relation to gold thioglucose obesity: Am. Jour. Physiology, v. 202, p. 743-750.

Deul, Maurice, 1958, Biochemical and geochemical origins of ash-forming ingredients in coal: Am. Chem. Soc. Mtg., Chicago, Ill., Sept. 1958, Div. Gas and Fuel Chemistry, preprint, p. 169-182.

DeWilde, P., 1905, Sur l'or contenu dans l'eau de la mer: Archives, Sci., Soc. de phys. et d'hist. nat., v. 19, p. 559-580.

Don, J. R., 1898, The genesis of certain auriferous lodes: Am. Inst. Mining Engineers Trans., v. 27, p. 564-668.

Fischer, K. W., 1966, Edelmetalle in der Saale und in ihrem Einzugsgebiet: Geologie, v. 15, p. 550-561.

Friedensburg, Ferdinand, with a contribution by Heinrich Quiring, 1953, Die Metallischen Rohstoffe, ihre Lagerungsverhaltnisse und ihre wirtschaftliche Bedeutung Gold, 2d ed.: Stuttgart, Ferdinand Enke-Verlag, 256 p.

Fukai, Rinnosuke, and Meinke, W. W., 1962, Activation analysis of vanadium, arsenic, molybdenum, tungsten, rhenium and gold in marine organisms: Limnology and Oceanography, v. 7, p. 186-200.

Glazunov, A. I., 1929, L'or contenu dans l'eau de mer: Chimie et Industrie, v. 21, spec. no., p. C426-C427.

Gmelin, Leopold, 1954, Gmelins Handbuch der anorganischen Chemie, System-nummer 62, Gold, pt. 2: Weinheim/Bergstrasse, Verlag Chemie, GmbH, 406 p.

Gourevitch, Alexandre, 1933, Sur l'or de l'eau de mer: Chimie et Industrie, v. 29, p. 284.

Grange, L. I., 1937, The geology of the Rotorua-Taupo subdivisions: New Zealand Geol. Survey Bull., no. 37 (n. ser.), $138 \mathrm{p}$. 
Haber, Fritz, 1927, Das Gold im Meerwasser: Zeitschr. angew. Chemie, v. 40, p. 303-314.

1928, Das Gold im Meere: Gesell. Erdkunde Berlin Zeitschr., Ergänzungsheft 3, p. 3-12.

Haber, Fritz, and Jaenicke, Johannes, 1925, Beitrag zur Kenntnis des Rheinwassers: Zeitschr. anorg. u. allg. Chemie, v. 147, p. 156-170.

Hummel, R. W., 1957, Determination of gold in sea water by radioactivation analysis: Analyst, v. 82 , p. $483-$ 488.

Ikeda, Nagao, 1955a, The hot springs of Nasu IX: Nippon Kagaku Zasshi, v. 76, p. 833-836 (in Japanese).

$-1955 \mathrm{~b}$, Chemical studies on the hot springs of Nasu XI: Nippon Kagaku Zasshi, v. 76, p. 1071-1073 (in Japanese).

Jones, R. S., 1968, Gold in meteorites and in the Earth's crust: U.S. Geol. Survey Circ. 603, 4 p.

-1969, Gold in igneous, sedimentary, and metamorphic rocks: U.S. Geol. Survey Circ. 610, 28 p.

Jones, R. S., and Fleischer, Michael, 1969, Gold in minerals and the composition of native gold: U.S. Geol. Survey Circ. 612, 17 p.

Kalistratova, V. S., Moskalev, Yu, I., and Serebryakov, N. G., 1966, Effect of administration rate on the behavior of colloidal gold $\left({ }^{198} \mathrm{Au}\right)$ in white rats: Raspredel. Biol. Deistvie, Radioaktiv. Izotop., Sb. State, p. 36-44 (in Russian).

Katakura, Yasuhiro, 1965, Neutron activation analysis in the determination of colloidal gold and lutecium in biological materials: Tohoku Univ. Sci. Rept., Ser. C 12, p. 223-239.

Khotamov, Sh., Lobanov, E. M., and Kist, A. A., 1966, The problem of the concentration of gold in organs of plants within ore fields: Akad. Nauk Tadzhik. SSR Doklady, v. 9, no. 11, p. 27-30 (in Russian).

Koch, Hellmuth, 1918, Ueber die Adsorption von Natriumaurichlorid an Kohle und die Bestimmung des Goldes im Meerwasser: Kolloid-Zeitschr., v. 22, no. 1, p. 1-22.

Koga, Akito, 1960, Chemical studies on the hot springs of Beppu. I. Trace elements in the Beppu hot springs: Onken Kiyo, v. 12, p. 52-60 (in Japanese, with English summary).

1961, Chemical studies on the hot springs of Beppu. XXV. Distribution of gold: Nippon Kagaku Zasshi, v. 82, p. 1476-1478 (in Japanese, with English summary).

Konovalov, E. P., 1941, Hydrochemical method of prospecting for gold: Sovetskaya Geologiya, 1941, no. 2, p. 114-117 (in Russian).

Kropachev, C. K., 1935, The distribution of $\mathrm{Au}$ in nature: Sovetskaya Zolotoprom., 1935, no. 8, p. $46-47$ (in Russian).

Landstrom, O., and Wenner, C. G., 1965, Neutron activation analysis of natural water applied to hydrology: Aktiebolaget Atomenergi, Stockholm, AE-204, 15 p.

Lincoln, F. C., 1911, Certain natural associations of gold: Econ. Geology, v. 6, p. 247-302.

Liversidge, Archibald, 1897, Presence of gold in natural saline deposits and marine plants: Chem. Soc. [London] Jour., v. 71, p. 298-299.

Lundberg, Max, Soeremark, Rune, and Thilander, Holger, 1965, The concentration of some elements in the enamel of unerupted (impacted) human teeth: Odontol. Revy., v. 16, p. 8-11.
Lungwitz, E. E., 1899, Der geologische Zusammendhand von Vegetation and Goldlagerstätten: Zeitschr. prakt. Geologie, v. 9, p. 71-74 [1900].

Maclaren, J. M., 1906, The source of the waters of geyers: Geol. Mag., v. 3, p. 411-514.

Malte-Brun, Conrad, 1847, A system of universal geography, v. 1: Boston, Samuel Walker, 640 p.

Malyuga, D. P., 1964, Biochemical methods of prospecting · New York, Consultants Bur., 205 p.

Noddack, Ida, and Noddack, Walter, 1939, Die Häufigkeiten der Schwermetalle in Meerestieren: Arkiv Zoologie, v. 32A, no. 4, p. 1-35.

Oka, Yochinaga, Kato, Toyoaki, and Sasaki, Michio, 1964, Determination of gold in sea water by neutron activation analysis: Nippon Kagaku Zasshi, v. 85, p. 643-647 (in Japanese, with English summary).

Pack, J. W., 1898, Gold from sea water: Mining and Sci. Press, v. 77, no. 7, p. 154-155.

Parr, R. M., and Taylor, D. M., 1963, Determination of Gold in human liver by thermal neutron activation analysis: Physics in Medicine and Biology, v. 8, p. 43-50.

Peshchevitskii, B. I., Anoshin, G. N., and Erenburg, A. M., 1965, Chemical forms of gold in sea water: Akad. Nauk SSSR Doklady, v. 162, no. 4, p. 915917 (in Russian).

Putnam, C. L., 1953, The gold content of sea water: Jour. Chem. Education, v. 30, p. 576-579.

Razin, L. V. and Rozhkov, I. S., 1963, Gold geochemistry in the crust of weathering and the biosphere of a permafrost province in the Aldan Shield: Akad. Nauk SSSR Yakut. Fil. Sibiroskoye Otdeleniye Trudy, Geol. Ser., v. 16, p. 5-22 (in Russian).

1966, Geochemistry of gold in the crust of weathering and in the biosphere in the gold-ore deposits of the Kuranakh type: Izdatellstvo "Nauka" Moskva, 256 p. (in Russian).

Schutz, D. F., and Turekian, K. K., 1965, Geographical and vertical distribution of several trace elements in sea water using neutron activation analysis: Geochim. et Cosmochim. Acta, v. 29, no. 4, p. 259-313.

Shacklette, H. T., 1965, Element content of bryophytes: U.S. Geol. Survey Bull. 1198-D, 21 p.

Soeremark, Rune, and Samsahl, Knut, 1962, Gamma-ray spectrometric analysis of elements in normal human dentin: Jour. Dental Research, v. 41, p. 603-606.

Sonstadt, Edward, 1872, On the presence of gold in sea water: Chem. News, v. 26, p. 169-171.

Stark, Walter, 1943, Gold from sea water: Helvetica Chimica Acta, v. 26, p. 424-441.

Vinogradov, A. P., 1953, The elementary chemical composition of marine organisms: New Haven, Sears Found. Marine Research, mem. 2, 647 p.

Wagoner, Luther, 1901, The detection and estimation of small quantities of gold and silver: Am. Inst. Mining Engineers Trans., v. 31, p. 798-810.

Warren, H. V. and Delavault, R. E., 1950, Gold and silver content of some trees and horsetails (Equisetum spp.) in British Columbia: Geol. Soc. America Bull., v. 61, p. 123-128.

Weiss, H. V. and Lai, Ming-Gon, 1963, Cocrystallization of ultramicroquantities of elements with 2-mercaptobenzimadazole. Determination of gold in sea water: Anal. Chim. Acta. v. 28, p. 242-248. 
Weissberg, B. G., 1969, Gold-silver ore-grade precipitates from New Zealand thermal waters: Econ. Geology, v. 64, p. 95-108.

White, D. E., 1967, Mercury and base-metal deposits with associated thermal and mineral water, [Chapter] 13, in Barnes, H. L., ed., Geochemistry of hydrothermal ore deposits: New York, Holt, Rinehart, and Winston, p. 575-631.

Yasuda, Mataichi, 1927, The estimation of gold and silver in sea water: Chem. Soc. Japan Bull. 2, p. 321-323.

1928, The precipitation of gold and silver from their dilute solutions: Chem. Soc. Japan Bull. 3, p. 113-118.

Zenkevich, L. A., 1963, Biology of the seas of the USSR: New York, Interscience Publishers, 955 p.

Zvyagintzev, O. E., 1941, Geochemistry of gold: Akad. Nauk SSSR Inst. Obsch. i Neorgan. Khimii, 114 p. (in Russian). 
